\title{
A study of antimicrobial and antifungal activity of 2-((5-(2-bromophenyl)-4-substituted-4H-1,2,4-triazol-3-yl)thio)acetates
}

\author{
A. A. Safonov ${ }^{* B, C, D}$, A. V. Nevmyvaka ${ }^{A-F}$ \\ Zaporizhzhia State Medical University, Ukraine
}

A - research concept and design; B - collection and/or assembly of data; C - data analysis and interpretation; D - writing the article;

$\mathrm{E}$ - critical revision of the article; $\mathrm{F}$ - final approval of the article

Bacteria and fungi are among the most ancient creatures found on Earth. Since the advent of medicine, humankind has always sought new means and ways to combat these microorganisms. In modern scientific society, the tendency to seek new antimicrobial and antifungal agents is only increasing. 1,2,4-triazole derivatives, among which effective drugs and new molecules have already been found, make quite an interesting platform for the creation of new antifungal and antimicrobial agents. A promising direction for the search for antimicrobial and antifungal agents are 2-((5-(2-bromophenyl)-4-substituted-4H-1,2,4-triazol-3-yl)thio)acetates.

The aim of work was the investigation of antimicrobial and antifungal activity among new 2-((5-(2-bromophenyl)-4-substituted-4H-1,2,4triazol-3-yl)thio)acetates.

Materials and methods. The substances were synthesized at the Department of Natural Sciences for International Students and Toxicological Chemistry. The antimicrobial and antifungal activity of the newly synthesized 2-((5-(2-bromophenyl)-4-substituted-4H-1,2,4triazol-3-yl)thio)acetates was studied with the method of serial dilutions. Staphylococcus aureus ATCC 25923, Escherichia coli ATCC 25922 , Pseudomonas aeruginosa ATCC 27853, and Candida albicans ATCC 885-653 were used as a set of standard test strains.

Results. As a result, the antimicrobial and antifungal activity of 14 new compounds was investigated. The most active compounds with antifungal effect are IIf-Ilh. Substances IIf-IIh and Ilj, Ilk have moderate antimicrobial effect to P. aeruginosae.

Conclusions. Some results are obtained regarding "structure - antimicrobial and antifungal effect" dependence: the replacement of the ethyl radical with phenyl or methyl in the fourth position of the 1,2,4-triazole cycle in the 2-((5-(2-bromophenyl)-4-R-4H-1,2,4-triazol-3yl)thio)acetate acid molecule results in reduction of the antimicrobial effect; conversion to 2-((5-(2-bromophenyl)-4-substituted-4H-1,2,4triazol-3-yl)thio)acetate salts and the choice of dimethylammonium as cation leads to an increase in the antimicrobial and antifungal effect.

Key words: antimicrobial activity, antifungal activity, triazoles, acids, salts, heterocyclic compounds.

Current issues in pharmacy and medicine: science and practice 2020; 13 (3), 359-364

Дослідження протимікробної та протигрибкової активності 2-((5-(2-бромфеніл)-4-заміщених-4Н-1,2,4-тріазол-3-іл)тіо) ацетатів

\section{А. А. Сафонов, А. В. Невмивака}

Бактерії та грибки - одні з найдавніших істот на Землі. 3 появою медицини людство шукає нові засоби та способи боротьби 3 цими мікроорганізмами. У сучасній науковій спільноті посилюється тенденція до пошуку нових протимікробних і протигрибкових засобів. Досить цікава платформа для створення нових протигрибкових і протимікробних засобів - похідні 1,2,4-тріазолу, серед них уже знайдені ефрективні лікарські засоби та нові молекули. Перспективний напрям для пошуку протимікробних і протигрибкових засобів - 2-((5-(2-бромфеніл)-4-заміщені-4H-1,2,4-тріазол-3-іл)тіо)ацетати.

Мета роботи - дослідити протимікробну та протигрибкову активність серед нових 2-((5-(2-бромфеніл)-4-заміщених-4Н-1,2,4тріазол-3-іл)тіо)ацетатів.

Матеріали та методи. Речовини, що досліджували, синтезовані на кафедрі природничих дисциплін для іноземних студентів та токсикологічної хімії Запорізького державного медичного університету. Протимікробну та протигрибкову активність нових синтезованих 2-((5-(2-бромофеніл)-4-заміщених-4Н-1,2,4-тріазол-3-іл)тіо)ацетатів досліджували методом серійних розведень. Використали набір стандартних тестових штамів Staphylococcus aureus ATCC 25923, Pseudomonas aeruginosa ATCC 27853, Escherichia coli ATCC 25922, Candida albicans ATCC 885-653.

ARTICLE

INFO

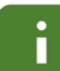

http:l/pharmed.

zsmu.edu.ualarticle/ view/216209
UDC 615.281/282.015:547.792

DOI: $10.14739 / 2409-2932.2020 .3 .216209$

Current issues in pharmacy and medicine: science and practice $2020 ; 13$ (3), 359-364

Key words: antimicrobial activity, antifungal activity, triazoles, acids, salts, heterocyclic compounds

*E-mail: 8safonov@gmail.com

Received: 26.08.2020 // Revised: 03.09.2020 // Accepted: 07.09.2020 
Результати. Дослідили протимікробну та протигрибкову активність 14 нових сполук. Найактивніші сполуки 3 протигрибковим есректом - Ilf-Ilh. Речовини IIf-Illh та Ilj, Ilk мають помірну протимікробну дію на P. aeruginosae.

Висновки. Зробили висновки щодо залежності «структура - протимікробний і протигрибковий ефект»: заміна етилового радикала метиловим або феніловим у четвертому положенні 1,2,4-тріазолового циклу в молекулі 2-((5-(2-бромофеніл)-4-R-4H-1,2,4-тріазол-3-іл)тіо)ацетатної кислоти призводить до зменшення антимікробного ефректу; перехід до солей 2-((5-(2-бромофреніл)-4-заміщених-4H-1,2,4-тріазол-3-іл)тіо)ацетатних кислот і вибір диметиламонію як катіону призводить до збільшення протимікробного та протигрибкового ефректу.

Ключові слова: протимікробна та протигрибкова активність, 1,2,4-тріазол, кислоти, солі, гетероциклічні сполуки.

Актуальні питання фармацевтичної і медичної науки та практики. 2020. Т. 13, № 3(34). С. 359-364

Исследование противомикробной и противогрибковой активности 2-((5-(2-бромфенил)-4-замещенных-4H-1,2,4триазол-3-ил)тио)ацетатов

\section{А. А. Сафонов, А. В. Невмывака}

Бактерии и грибки - одни из самых древних существ на Земле. С появлением медицины человечество искало новые средства и способы борьбы с этими микроорганизмами. В современном научном сообществе тенденция к поиску новых противомикробных и противогрибковых средств только увеличивается.

Достаточно интересной платсрормой для создания новых противогрибковых и противомикробных средств являются производные 1,2,4-триазола, среди которых уже найдены эффективные лекарственные средства и новые молекулы. Перспективным направлением для поиска противомикробных и противогрибковых средств являются 2-((5-(2-бромфенил)-4-замещенные-4H-1,2,4-триазол-3-ил)тио)ацетаты.

Цель работы - исследование противомикробной и противогрибковой активности среди синтезированных ранее 2-((5-(2-бромфенил)-4-замещенных-4Н-1,2,4-триазол-3-ил)тио)ацетатов.

Материалы и методы. Исследуемые вещества синтезированы на кафедре естественных дисциплин для иностранных студентов и токсикологической химии. Противомикробную и противогрибковую активность новых синтезированных 2-((5-(2-бромофенил)-4-замещенных-4Н-1,2,4-триазол-3-ил)тио)ацетатов исследовали методом серийных разведений. Использован набор стандартных тестовых штаммов Staphylococcus aureus ATCC 25923, Pseudomonas aeruginosa ATCC 27853, Escherichia coli ATCC 25922, Candida albicans ATCC 885-653.

Результаты. Исследовано противомикробное и противогрибковое действие 14 новых соединений. Самые активные соединения с противогрибковым эффектом - IIf-Illh. Вещества IIf-Ilh и Ilj, Ilk имеют умеренное противомикробное действие на P. aeruginosae.

Выводы. Сделаны выводы о зависимости «структура - противомикробный и противогрибковый эффект»: замена этилового радикала метиловым или фениловым в четвертом положении 1,2,4-триазолового цикла в молекуле 2-((5-(2-бромофенил)-4-R4H-1,2,4-триазол-3-ил)тио)ацетатной кислоты приводит к уменьшению противомикробного эффекта; переход к солям 2-((5-(2-бромофенил)-4-замещенных-4Н-1,2,4-триазол-3-ил)тио)ацетатных кислот и выбор диметиламмония как катиона ведет к увеличению противомикробного и противогрибкового эффекта.

Ключевые слова: противомикробная и противогрибковая активность, 1,2,4-триазол, кислоты, соли, гетероциклические соединения.

Актуальные вопросы фрармацевтической и медицинской науки и практики. 2020. Т. 13, № 3(34). С. 359-364

Modern people probably cannot imagine their lives without vitamins, painkillers, antimicrobials, antivirals, antifungals, etc. As a result, bacteria that used to be eliminated with conventional penicillin in the 20th century, at present have become resistant even to more sophisticated antibiotics.

The thirst for existence and the constant transformation of bacteria encourages scientists around the world to create new and new antimicrobials. Certainly, it is much easier to create an active molecule on an already known platform, which has proven itself as a biologically active nucleus [1-4].

New 2-((5-(2-bromophenyl)-4-substituted-4H-1,2,4-triazol-3-yl)thio)acetates have been insufficiently studied by far [5-13].

\section{Aim}

That's why the aim of this work is to investigate antimicrobial and antifungal activity of new 2-((5-(2-bromophenyl)-4-substituted-4H-1,2,4-triazol-3-yl)thio)acetates.

\section{Materials and methods}

Antimicrobial and antifungal activity of the newly synthesized 2-((5-(2-bromophenyl)-4-substituted-4H-1,2,4-triazol-3-yl)thio)acetates was investigated with the method of serial dilutions according to guidelines [14]. The synthesized compounds were prepared by double serial dilutions, with the initial concentration of $1 \mathrm{mg} / \mathrm{ml}$ in Mueller-Hinton broth, in the volume of $1 \mathrm{ml}$. Then $0.1 \mathrm{ml}$ of microbial curtain (106 $\mu / \mathrm{ml})$ was added. Minimum inhibitory concentration (MIC) was determined without visible growth in a test tube with a minimum concentration of the drug; the minimum bactericidal/fungicidal concentration $(\mathrm{MBcC}, \mathrm{MFcC})$ was determined without growth on agar after inoculation from transparent tubes. The synthesized compounds were dissolved in dimethylsulfoxide.

A set of standard test strains of Staphylococcus aureus ATCC 25923, Pseudomonas aeruginosa ATCC 27853, Escherichia coli ATCC 25922, Candida albicans ATCC 
885-653 was used. CHLORHEXEDINE-ZDOROV`E® (Ukraine) and FLUCONAZOLE-DARNYTSYA ${ }^{\circledR}$ (Ukraine) were used as comparative drugs.

\section{Results}

As a result, the antimicrobial and antifungal activity of 14 new compounds was investigated.

The most active compounds with antifungal effect are IIf-IIh. Substances IIf-IIh and IIj, IIk have moderate antimicrobial effect to $P$. aeruginosae.

Some conclusions have been made regarding "structure biological activity" dependence.

\section{Discussion}

The antimicrobial and antifungal activity of 2-((5-(2-bromophenyl)-4-substituted-4H-1,2,4-triazol-3-yl)thio)acetate acids is moderate. The most active compound is $\mathrm{Ib}$ (2-((5-(2-bromophenyl)-4-ethyl-4H-1,2,4-triazol-3-yl)thio) acetate acid) (Table 1,2).

The replacement of the ethyl radical with phenyl or methyl in the fourth position of the 1,2,4-triazole cycle in the 2-((5-(2-bromophenyl)-4-R-4H-1,2,4-triazol-3-yl)thio)acetate acid molecule results in antimicrobial effect reduction (Fig. 1).

Considering the antifungal activity of 2-((5-(2-bromophenyl)-4-substituted-4H-1,2,4-triazol-3-yl)thio)acetate salts, the compounds IIf, IIg, IIh demonstrate antifungal effect, respectively, MIC $31.25 \mu \mathrm{g} / \mathrm{ml}$, MFcC $32.25 \mu \mathrm{g} / \mathrm{ml}$. Replacement of the potassium cation either with sodium or
Table 1. "Structure - effect" dependence between 2-((5-(2-bromophenyl)4-substituted-4H-1,2,4-triazol-3-yl)thio)acetate acids
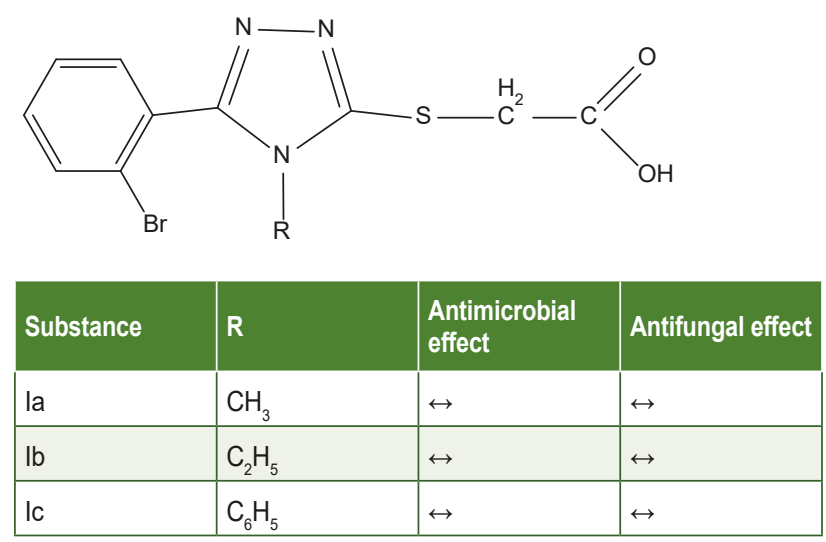

dimethylammonium or 2-aminoethanol reduces antifungal activity (Table 3).

A study of the antimicrobial activity of 2-((5-(2-bromophenyl)-4-substituted-4H-1,2,4-triazol-3-yl)thio)acetate salts showed that the most active compounds to P. aeruginosae are substances IIf - IIh and IIj, IIk. Thus, the introduction of dimethylammonium cation to the molecule of 2-((5-(2-bromophenyl)-4-substituted-4H-1,2,4-triazol-3-yl)thio)acetate acid leads to an increase in the antimicrobial effect. Also, the introduction of ethyl and phenyl radical in position 4 to the 2-((5-(2-bromophenyl)-4-substituted-4H-1,2,4-triazol-3yl)thio)acetate acid molecule leads to a positive antimicrobial effect (Fig. 2)

Table 2. Antimicrobial and antifungal activity of 2-((5-(2-bromophenyl)-4-substituted-4H-1,2,4-triazol-3-yl)thio)acetate acids and salts

\begin{tabular}{|c|c|c|c|c|c|c|c|c|}
\hline & \multicolumn{6}{|c|}{ Antimicrobial activity } & \multirow{2}{*}{\multicolumn{2}{|c|}{\begin{tabular}{|l} 
Antifungal activity \\
C. albicans
\end{tabular}}} \\
\hline & \multicolumn{2}{|c|}{ E. coli ATCC 25922} & \multicolumn{2}{|c|}{ S. aureus ATCC 25923} & \multicolumn{2}{|c|}{$P$. aeruginosae ATCC 27853} & & \\
\hline & MIC, $\mu \mathrm{g} / \mathrm{ml}$ & $\mathrm{MBcC} \mu \mathrm{g} / \mathrm{ml}$ & MIC, $\mu \mathrm{g} / \mathrm{ml}$ & $\mathrm{MBcC} \mu \mathrm{g} / \mathrm{ml}$ & MIC, $\mu \mathrm{g} / \mathrm{ml}$ & $\mathrm{MBcC} \mu \mathrm{g} / \mathrm{ml}$ & MIC, $\mu \mathrm{g} / \mathrm{ml}$ & $\mathrm{MFcC}, \mu \mathrm{g} / \mathrm{ml}$ \\
\hline Chlorhexidine & - & 25.0 & - & 18.8 & - & 200 & - & - \\
\hline Fluconazole & & & & & & & 15.6 & 31.25 \\
\hline la & 125 & 125 & 62.5 & 125 & 62.5 & 125 & 62.5 & 125 \\
\hline $\mathrm{lb}$ & 62.5 & 125 & 62.5 & 125 & 62.5 & 125 & 62.5 & 125 \\
\hline Ic & 125 & 125 & 62.5 & 125 & 62.5 & 125 & 62.5 & 125 \\
\hline Ila & 62.5 & 125 & 62.5 & 125 & 62.5 & 125 & 62.5 & 125 \\
\hline llb & 62.5 & 125 & 62.5 & 125 & 62.5 & 125 & 62.5 & 62.5 \\
\hline IIc & 62.5 & 125 & 62.5 & 125 & 62.5 & 125 & 62.5 & 62,5 \\
\hline Ild & 62.5 & 125 & 62.5 & 125 & 62.5 & 125 & 62.5 & 125 \\
\hline Ile & 125 & 250 & 62.5 & 125 & 62.5 & 125 & 62.5 & 125 \\
\hline Ilf & 62.5 & 62.5 & 62.5 & 125 & 31.25 & 62.5 & 3125 & 31.25 \\
\hline Ilg & 62.5 & 125 & 62.5 & 125 & 31.25 & 62.5 & 31.25 & 31.25 \\
\hline Ilh & 62.5 & 125 & 62.5 & 125 & 31.25 & 62.5 & 31.25 & 31.25 \\
\hline Ili & 62.5 & 125 & 62.5 & 125 & 62.5 & 125 & 31.25 & 62.5 \\
\hline Ilj & 62.5 & 125 & 62.5 & 125 & 31.25 & 62.5 & 125 & 125 \\
\hline Ilk & 62.5 & 125 & 62.5 & 125 & 31.25 & 62.5 & 125 & 125 \\
\hline
\end{tabular}




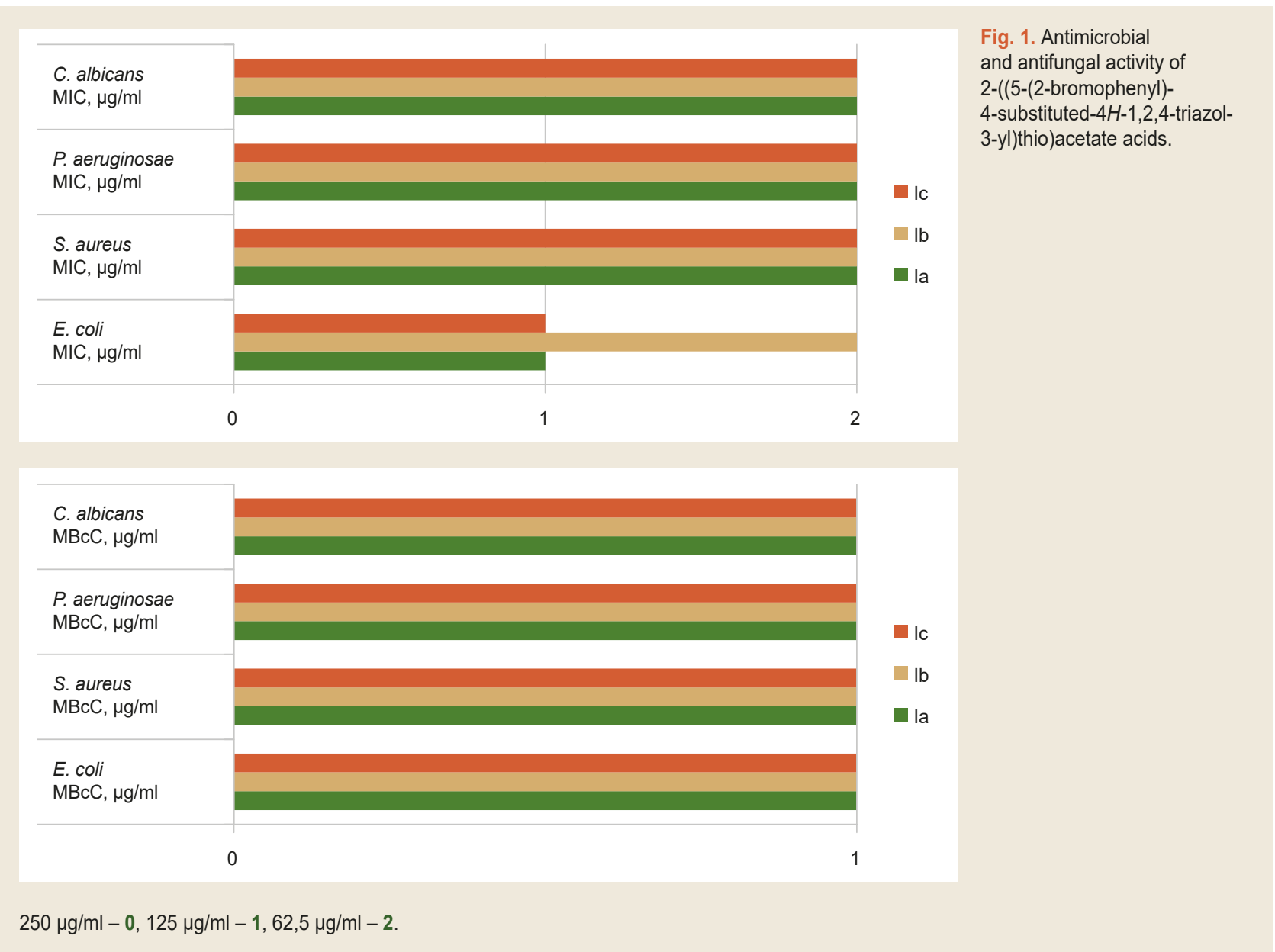

Table 3. "Structure - activity" dependence between 2-((5-(2-bromophenyl)4-substituted-4H-1,2,4-triazol-3-yl)thio)acetate salts<smiles>[X]n1c(SCC(=O)[O-])nnc1-c1ccccc1Br</smiles>

\begin{tabular}{|l|l|l|l|l|} 
Substance & $\mathbf{R}$ & $\mathbf{X}$ & $\begin{array}{l}\text { Antimicrobial } \\
\text { effect }\end{array}$ & $\begin{array}{l}\text { Antifungal } \\
\text { effect }\end{array}$ \\
\hline Illa & $\mathrm{CH}_{3}$ & $\mathrm{~K}$ & $\leftrightarrow$ & $\leftrightarrow$ \\
\hline Ilb & $\mathrm{CH}_{3}$ & $\mathrm{Na}$ & $\leftrightarrow$ & $\leftrightarrow$ \\
\hline Ilc & $\mathrm{CH}_{3}$ & $\left(\mathrm{CH}_{3}\right)_{2} \mathrm{NH}$ & $\leftrightarrow$ & $\leftrightarrow$ \\
\hline Ild & $\mathrm{CH}_{3}$ & 2 -aminoethanol & $\leftrightarrow$ & $\leftrightarrow$ \\
\hline Ile & $\mathrm{C}_{2} \mathrm{H}_{5}$ & $\mathrm{Na}$ & $\downarrow$ & $\leftrightarrow$ \\
\hline Ilf & $\mathrm{C}_{2} \mathrm{H}_{5}$ & $\left(\mathrm{CH}_{3}\right)_{2} \mathrm{NH}$ & $\uparrow$ & $\uparrow$ \\
\hline Ilg & $\mathrm{C}_{2} \mathrm{H}_{5}$ & morpholine & $\uparrow$ & $\uparrow$ \\
\hline Ilh & $\mathrm{C}_{6} \mathrm{H}_{5}$ & $\mathrm{~K}$ & $\uparrow$ & $\uparrow$ \\
\hline Ili & $\mathrm{C}_{6} \mathrm{H}_{5}$ & $\mathrm{Na}$ & $\leftrightarrow$ & $\uparrow$ \\
\hline Ilj & $\mathrm{C}_{6} \mathrm{H}_{5}$ & $\left(\mathrm{CH}_{3}\right)_{2} \mathrm{NH}$ & $\uparrow$ & $\leftrightarrow$ \\
\hline Illk & $\mathrm{C}_{6} \mathrm{H}_{5}$ & 2 -aminoethanol & $\uparrow$ & $\leftrightarrow$ \\
\hline
\end{tabular}

It should be noted that the compound IIf (dimethylammonium 2-((5-(2-bromophenyl)-4-ethyl-4H-1,2,4-triazol-3-yl) thio)acetate), while investigating the antimicrobial activity of 2-((5-(2-bromophenyl)-4-substituted-4H-1,2,4-triazol-3yl)thio)acetate salts against $E$. coli, has a slightly stronger bactericidal effect comparing to other compounds.

The antimicrobial activity to $S$. aureus is moderate and similar to all 2-((5-(2-bromophenyl)-4-substituted-4H-1,2,4triazol-3-yl)thio)acetate salts.

As a result of the research it should be noted that the conversion to 2-((5-(2-bromophenyl)-4-substituted-4H-1,2,4-triazol3 -yl)thio)acetate salts and the choice of dimethylammonium as cation leads to an increase in the antimicrobial and antifungal effects.

\section{Conclusions}

As a result, the antimicrobial and antifungal activity of 14 new 2-((5-(2-bromophenyl)-4-substituted-4H-1,2,4-triazol3 -yl)thio)acetates has been investigated.

Compounds with antifungal effect are IIf-IIh. Substances IIf-IIh and IIj, IIk have moderate antimicrobial effect to $P$. aeruginosae. But none of the compounds surpasses the comparison drug.

Some conclusions are drawn regarding the "structure antimicrobial and antifungal effect" dependence: 


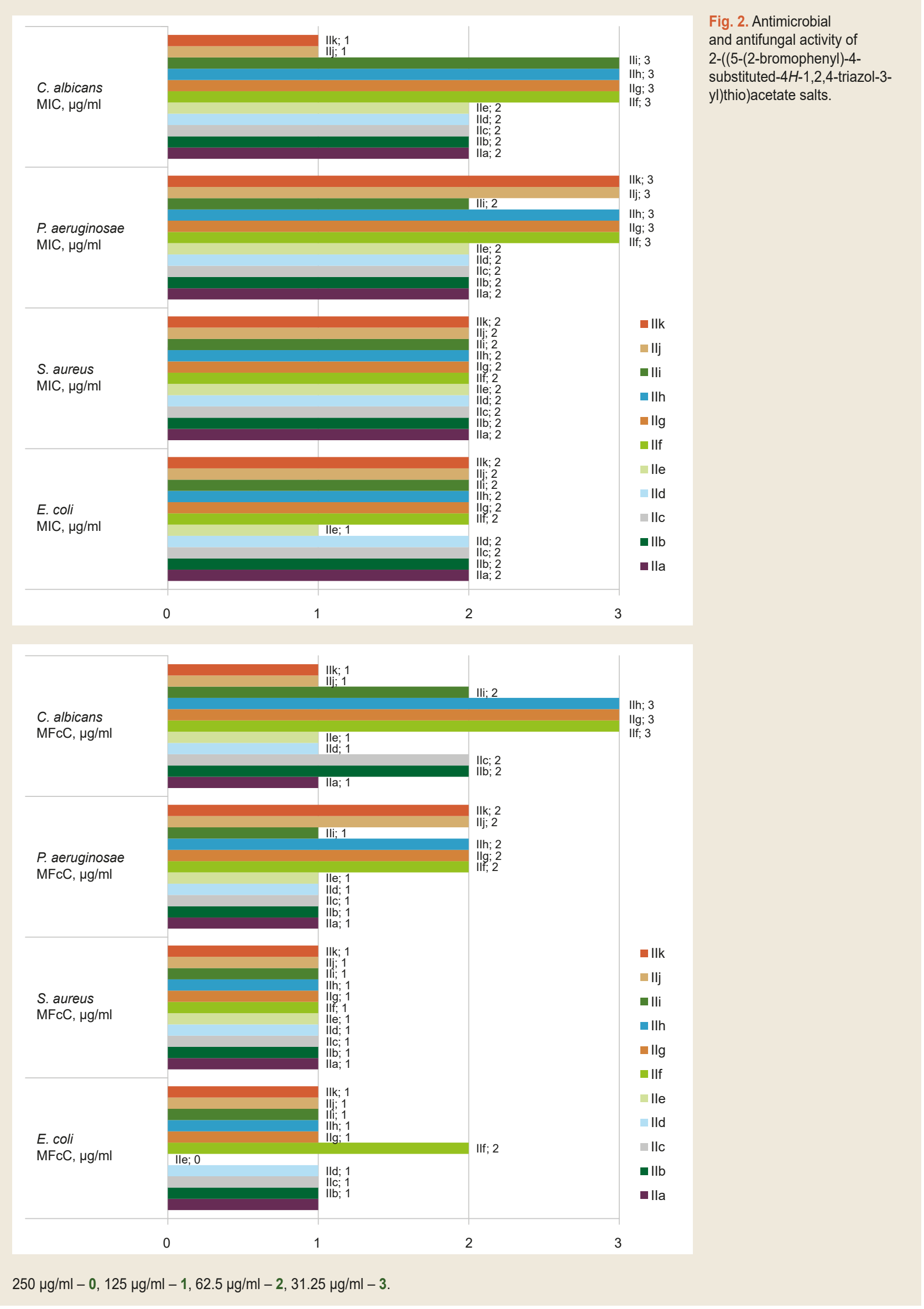


- the replacement of the ethyl radical with methyl or phenyl in the fourth position of the 1,2,4-triazole cycle in the 2-((5-(2-bromophenyl)-4-R-4H-1,2,4-triazol-3-yl)thio) acetate acid molecule results in the antimicrobial effect reduction;

- conversion to 2-((5-(2-bromophenyl)-4-substituted4H-1,2,4-triazol-3-yl)thio)acetate salts and the choice of dimethylammonium as a cation leads to an increase in the antimicrobial and antifungal effect.

\section{Funding}

The research is carried out in the framework of the research activities of Zaporizhzhia State Medical University "Synthesis, modification and study of the properties of 1,2,4-triazole derivatives aimed at creating an antimicrobial drug", state registration number 0120 U101649.

Conflicts of interest: authors have no conflict of interest to declare. Конфлікт інтересів: відсутній.

Information about authors:

Safonov A. A., PhD, Associate Professor of the Department of Natural Sciences for Foreign Students and Toxicological Chemistry, Zaporizhzhia State Medical University, Ukraine.

Nevmyvaka A. V., Senior Laboratory Assistant of the Department of Pharmacology, Pharmacognosy and Botany, Zaporizhzhia State Medical University, Ukraine.

\section{Відомості про авторів:}

Сафонов А. А., канд. фрарм. наук, доцент каф. природничих дисциплін для іноземних студентів та токсикологічної хімії, Запорізький державний медичний університет, Україна.

Невмивака А. В., старший лаборант каф. фармакології, фармакогнозії та ботаніки, Запорізький державний медичний університет, Україна.

Сведения об авторах:

Сафонов А. А., канд. фрарм. наук, доцент каф. естественных дисциплин для иностранных студентов и токсикологической химии, Запорожский государственный медицинский университет, Украина. Невмывака А. В., старший лаборант каф. фармакологии, фармакогнозии и ботаники, Запорожский государственный медицинский университет, Украина.

\section{References}

[1] Shcherbak, M. A., Kaplaushenko, A. G., Maletskiy, N. N., \& Sharaya, Ye. A. (2014). The research on creation the dosage form based on 3-(4-nitrophenyl)-5-(nonylsulfonyl)-1,2,4-triazol-4-amine. Zaporozhye Medical Journal, (4), 82-85.

[2] Kaplaushenko, A. H. (2013). Doslidzhennia zi stvorennia novoho oryhinalnoho vitchyznianoho likarskoho zasobu na osnovi 1,2,4-triazolu [The research of creating a new original domestic drug based on 1,2,4-triazole]. Naukovyi zhurnal MOZ Ukrainy, 2(3), 115-121. [in Ukrainian].

[3] Shcherbyna, R. O. (2014). Analiz farmakolohichnoi aktyvnosti pokhidnykh 1,2,4-triazolu [Analysis of pharmacological activity of 1,2,4-triazole derivatives]. Farmatsevtychnyi chasopys, (4), 145-150. [in Ukrainian].

[4] Li, Y. S., Tian, H., Zhao, D. S., Hu, D. K., Liu, X. Y., Jin, H. W. Song, G. P., \& Cui, Z. N. (2016). Synthesis and bioactivity of pyrazole and triazole derivatives as potential PDE4 inhibitors. Bioorganic \& medicinal chemistry letters, 26(15), 3632-3635. https://doi.org/10.1016/j. bmcl.2016.06.002

[5] Shcherbyna, R. O., Panasenko, O. I., \& Knysh, Ye. H. (2016). Vyvchennia antyoksydantnoi aktyvnosti solei 2-((4-R-3-(morfolinometylen)-4H1,2,4-tryazol-5-il)tio)atsetatnykh kyslot [The studying of antioxidant activity of salts 2-((4-R-3-(morpholinomethylen)-4H1,2,4-triazole-5-yl) thio)acetic acids]. Ukrainian Biopharmaceutical Journal, (1), 37-40. [in Ukrainian]

[6] Shcherbyna, R. O., Kapelyanovych, Ye. V., Pruhlo, Ye. S., Panasenko, O. I., \& Knysh, Ye. H. (2014). Doslidzhennia aktoprotektornoi aktyvnosti pokhidnykh 4-R-3-(morfolinometylen)-1,2,4-triazol-5-tiolu [The studying of actoprotective action of 4-R-3-(morpholinomethylene)-1,2,4-triazole-5-thiole derivatives]. Odeskyi medychnyi zhurnal, (6), 19-22. [in Ukrainian].

[7] Aksyonova, I. I., Shcherbyna, R. O., Panasenko, O. I., Knysh, Ye. H. \& Aksyonov, I. V. (2014). Doslidzhennia riststymuliuiuchoi aktyvnosti pokhidnykh 1,2,4-tryazolu na prykladi nasinnia soniashnyka prostoho [The investigation of growth-stimulating activity of derivatives of 1,2,4-triazole on seeds of sunflower simple]. Ukrainian Biopharmaceutical Journal, (6), 78-82. [in Ukrainian].

[8] Murty, M. S., Ram, K. R., Rao, R. V., Yadav, J. S., Rao, J., \& Velatooru, L. R. (2012). Synthesis of New S-alkylated-3-mercapto-1,2,4-triazole Derivatives Bearing Cyclic Amine Moiety as Potent Anticancer Agents. Letters in Drug Design \& Discovery, 9(3), 276-281. https:// doi.org/10.2174/157018012799129882

[9] Pillai, R., Karrouchi, K., Fettach, S., Armaković, S., Armakovic, S. Brik, Y., Taoufik, J., Radi, S., Faouzi, M. E., \& Ansar, M. (2019). Synthesis, spectroscopic characterization, reactive properties by DFT calculations, molecular dynamics simulations and biological evaluation of Schiff bases tethered 1,2,4-triazole and pyrazole rings. Journal of Molecular Structure, 1177, 47-54. https://doi.org/10.1016/j. molstruc.2018.09.037

[10] Shcherbyna, R. O., Panasenko, O. I., Knysh, Ye. H., \& Varynskyy, B. O. (2014). Syntez i fizyko-khimichni vlastyvosti 2-((4-R-3-(morfolinometylen)-4H-1,2,4-triazol-5-il)tio) atsetatnykh kyslot [Synthesis and physical-chemical properties of 2-((4-R-3-(morpholinomethylen)-4H-1,2,4-triazole-5yl)thio)acetic acid]. Current Issues in Pharmacy and Medicine: Science and Practice, (3), 18-21. [in Ukrainian]. https:// doi.org/10.14739/2409-2932.2014.3.30016

[11] El-Sherief, H. A., Youssif, B. G., Bukhari, S. N., Abdelazeem, A., Abdel-Aziz, M., \& Abdel-Rahman, H. M. (2018). Synthesis, anticancer activity and molecular modeling studies of 1,2,4-triazole derivatives as EGFR inhibitors. European journal of medicinal chemistry, 156 774-789. https://doi.org/10.1016/j.ejmech.2018.07.024

[12] Samelyuk, Yu. H., \& Kaplaushenko, A. H. (2015). Hostra toksychnist 5-(23-, 4-metoksyfenil, (3,4,5-trymetoksyfenil)-)-1,2,4-triazol-3-tioniv ta yikh tiopokhidnykh [Acute toxicity of 5-(2-, 3-, 4-methoxyphenyl, (3,4,5-trimethoxyphenyl)-)-1,2,4-triazole-3-thiones and their thioderivatives]. Current Issues in Pharmacy and Medicine: Science and Practice, (3), 57-60. [in Ukrainian]. https://doi.org/10.14739/2409- 2932.2015.3.52660

[13] Safonov, A. A., \& Nevmyvaka, A. V. (2020). Synthesis of novel 3-(2-bromophenyl)-4-substituted-1H-1,2,4-triazole5(4H)-thiones derivatives. Current Issues in Pharmacy and Medicine: Science and Practice, 13(1), 11-16. https://doi.org/10.14739/2409-2932.2020.1.198087

[14] Volianskyi, Yu. L., Hrytsenko, I. S., \& Shyrobokov, V. P. (2004). Vyvchennia spetsyfichnoi aktyvnosti protymikrobnykh likarskykh zasobiv [Study of the specific activity of antimicrobial drugs]. Kyiv : Zdorovia. [in Ukrainian]. 